\title{
Stress-strain state of the lower traverse of the hydraulic press
}

\author{
Nemchynov S. I. ${ }^{*}$, Nachovnyi I. I.
}

State Higher Educational Institution "Ukrainian State University of Chemical Technology”, 8 Gagarina Av., 49005, Dnipro, Ukraine

\author{
Article info: \\ Paper received: \\ The final version of the paper received: \\ Paper accepted online:
}

\author{
October 24, 2017 \\ December 4, 2017 \\ January 9,2018
}

\author{
*Corresponding Author's Address: \\ sinonis@ukr.net
}

\begin{abstract}
In the present article the stress-strain state of the lower traverse of the central ejector of the hydraulic press for manufacturing large-sized plastic products has been investigated by using finite element analysis. It has been established that the stress-strain state of the traverse is characterized by a general and local uneven distribution of stresses and deformations; normal stresses in the cross section, passing through the plane of symmetry of the traverse, change linearly. Various changes of the equivalent stresses along the height on the inner surfaces of the central and lateral cylinders have been established. The zones of the traverse that are experiencing the highest values of normal and tangential stresses and strains have been identified. The research allowed to change the geometry of the traverse with a slight change in the stress and strain and therefore to reduce the weight of the traverse. This investigation and its results will have practical application in the design of new hydraulic presses as well as in improvement of existing hydraulic presses and are also the basis for further research.
\end{abstract}

Keywords: finite element method, geometry, stress, strain, displacement.

\section{Introduction}

Heavy-duty column hydraulic presses are widely used in many industries. The elements of the column frame, i.e. columns and traverses, are subject to high specific loads in the process of operation; therefore, their reliability determines the reliable performance of the press. The basic parts of a column hydraulic press make approximately $80 \%$ of its weight and cost [1]; traverses and tables are the most massive and costly of these. In the operation of hydraulic presses, a significant number of traverse failures is caused by fatigue, since cracks start developing in the high-stress areas. Therefore, the study of stress-strain state (SSS) and search for improving the form of the traverse are very important at the design stage and involve not only technical, but also economic aspects.

To calculate hydraulic press traverses, various simplified methods based on rod models were used over a long period of time.

With the advances in computer technology, numerical methods have been increasingly applied for the calculation of basic parts of hydraulic presses; among the methods, an important place is taken by the finite element method (FEM). Today, the software packages for finiteelement analysis, such as ANSYS, NASTRAN, SOLIDWORKS, ABAQUS, LIRA, SCAD, are used as a tool of numerical studies. Recently, free and open-source finite-element analysis applications, such as CalculiX, Elmer and Code_Aster, have been widely used. The above methods, unlike traditional ones that were based on the postulates of the strength of materials and theory of elasticity, allow a thorough study of a general SSS and of a distribution of local stresses in formulating twodimensional and three-dimensional problems. In many cases, this enables to dispense with experimental studies, although the latter retain their importance as a means of verifying the results of the SSS.

\section{Literature Review}

For today, there is some experience of designing traverses for hydraulic presses, but in most cases they have been calculated approximately, which can be explained by difficulties describing the stress-strain state and by structural features.

The analysis of publications shows that to determine the SSS of the hydraulic press basic elements, the authors use either methods based on the strength of materials [2], or FEM for the stress state only. For example, according to the existing methods of calculating the strength, the spatial structure of the traverse is replaced by two beams at the wide and narrow sides, and the cylinder force is applied to the centers of gravity of the reference semi- 
rings. This technique is simplistic and does not take into account the features of the traverse geometry, which is rather complicated. The technique does not provide a sufficiently complete picture of the SSS and, as a consequence, does not allow for recommendations on improving the traverse design.

In $[3,4]$, the frame of the P7640A hydraulic press was calculated using FEM in the ANSYS. Proceeding from the stress-strain analysis, the authors proposed a rational, from their point of view, form of the frame. However, the above studies have not proved that the proposed geometry of the frame ensures its strength and stiffness and can be considered optimal. No publications are available on a systematic study of the traverse strain state.

In [5] and [1] it has been established that the major cause of damage and fractures in the cross-members of heavy-duty presses is the emergence and propagation of fatigue cracks that appear in zones with high levels of stress, i.e. on the contours of technological and structural openings in the internal ribs, outer walls and plates under tension.

In [6], the major directions of retaining and improving the technological capabilities of heavy-duty hydraulic presses are outlined.

In the last decade, the scientific journals of the near and far abroad have published a sharply increased number of studies, which use various software packages of finite-element analysis to analyze the SSS of the frames of hydraulic and mechanical presses. On the basis of the SSS obtained, the authors optimized the geometry of the frames under study. Thus, in [7, 8], the ANSYS software was used to analyze the SSS of the frames of $0.2 \mathrm{MN}$ and $8 \mathrm{MN}$ hydraulic presses. The results of the study allowed changing the geometry of the frames with $50 \%$ and $23 \%$ decrease in their weights, respectively.

The results of calculating the stresses using the classical method of the strength of materials and the finiteelement method (FEM) were presented in [9] for a mechanical press frame. It was revealed that the values of stresses obtained by the classical method are higher than the values of stresses determined using FEM. In [9] it was also noted that the classical method may be used for verification.

The performed analysis showed that:

- most of the studies deal with the calculations of heavyduty hydraulic presses, while methods of calculating presses used in the chemical industry are practically unavailable;

- the data obtained in the studies are sometimes contradictory, and indicate the influence of one or another factor on the performance of the traverse;

- using FEM, which is currently the standard for calculating strength and stiffness, allows analyzing the SSS of any construction from a single position.

\section{Materials and Methods}

The purpose of the work is a stress-strain analysis of the lower traverse of the central ejector of a hydraulic press with a nominal pressing force of $20 \mathrm{MN}$ intended for the manufacture of large-sized plastic products, and justifying the proposed improvements in the traverse geometry.

The traverse of a hydraulic press, whose geometric model is presented in Figure 1, is subject to a uniformly distributed load. It is necessary to analyze its stress-strain state.

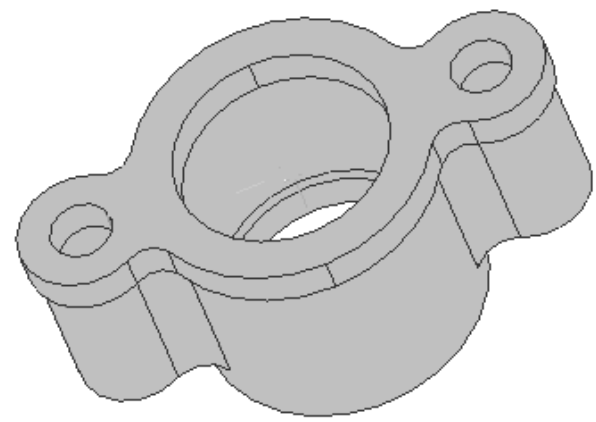

Figure 1 - The geometric model of the hydraulic press traverse

The hydraulic press traverse is a spatial construction of a complex configuration; therefore, analytical methods of calculation are practically unacceptable. The reliable results can only be obtained by numerical methods implemented on a computer. Therefore, to solve this threedimensional problem of the theory of elasticity, we apply FEM, which in our time is obviously the world standard for calculations of strength, stiffness and other parameters of structures.

FEM allows obtaining a system of algebraic equations

$$
[k] \cdot\{u\}=\{R\},
$$

where $[k]$ is the stiffness matrix of the finite-element model, $\{u\}$ is the nodal displacement vector, $\{R\}$ is vector of nodal forces.

Having solved the system (1), we find the displacement $u_{i}$, and following that we find stress $\sigma_{i j}$ and strain $\varepsilon_{i j}$ using the strain-displacement relations (Cauchy) and stress-strain relations (Hooke's law).

The application of FEM involves the simulation of the geometry of a construction and its meshing into finite elements, the formation of a global stiffness matrix and solving large systems of linear equations $\left(5 \cdot 10^{3}-5 \cdot 10^{5}\right)$. The above problems have prompted the authors to apply the SALOME-MECA platform-based, open-source Code_Aster application as a tool of numerical simulation. Code_Aster software allowed analyzing the SSS of the traverse, taking into account the features and modes of operation. 


\section{Results and Discussion}

The study is devoted to a numerical calculation of the SSS of the lower traverse of the hydraulic press central ejector. The overall dimensions of the traverse were $1440 \mathrm{~mm} \times 800 \mathrm{~mm} \times 650 \mathrm{~mm}$. The mass of the traverse was $747 \mathrm{~kg}$.

Prior to the simulation of a finite element model, a solid-state spatial model of the traverse (Figure 1) was created based on the working drawings. The model was made using the KOMPAS-3D system for three-dimensional modeling, which allows to effectively create models of complex forms. Taking into account the plane of symmetry (the form of the traverse, established boundary conditions, and applied loads); the stress-strain analysis was performed on half of the model.

The obtained half of the solid-state model was then transferred to the SALOME-MECA platform-based open source Code_Aster, which was used to set the boundary conditions, the load and the area where the load was applied, and to create a mesh of the finite-element model.

The boundary conditions were set so as to exclude the displacements of the traverse as an absolutely rigid body. According to the working conditions, the load on the lower traverse of the central ejector was assumed to be equal to the nominal ejection force of 3.24 MN. Figure 2 shows the calculation scheme and indicates the loads and boundary conditions.

Three-dimensional finite elements with a maximum size of $0.035 \mathrm{~m}$ were used for the discretization of the traverse as a spatial body. As a result of the discretization, a mesh of 9881 tetrahedra and 19241 nodes was obtained. The finite-element model of the traverse is shown in Figure $2 \mathrm{~b}$.

The material selected was $35 L$ steel with a Young's modulus $E=2 \cdot 10^{5} \mathrm{MPa}$, Poisson's ratio $v=0.32$, yield strength $\sigma_{y}=248 \mathrm{MPa}$, strength limit $\sigma_{\text {str }}=482 \mathrm{MPa}$.

As a result of the static calculation, the following parameters of the traverse SSS were obtained: stresses and strains along the corresponding axes; principal stresses and corresponding strains; equivalent stresses $\sigma_{e q}$ calculated by Guber-Mises energy theory of strength; total displacements; displacements along corresponding axes; factors of safety.

Given that cracks originate on high-stress surfaces, the changes in normal, tangential and equivalent stresses were studied on the internal surfaces of the central and lateral cylinders in sections I and II (Figure 3 a).

The performed calculations show that the stress-strain state of the traverse is characterized by general and local uneven distribution of stresses and displacements (Figure 3).

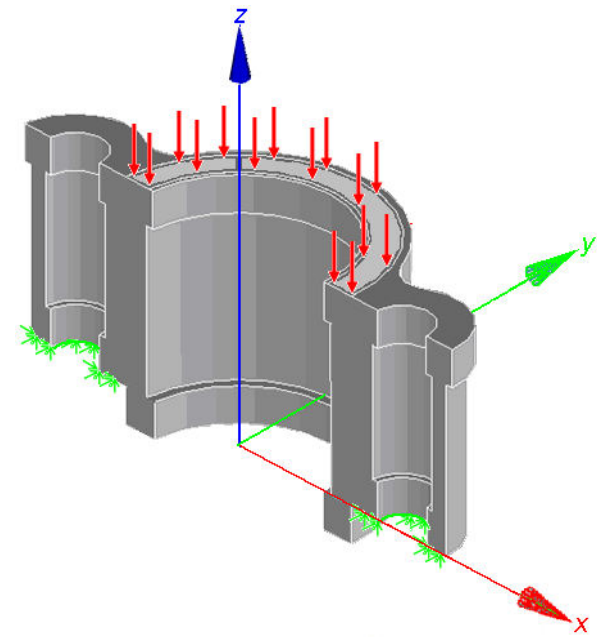

a

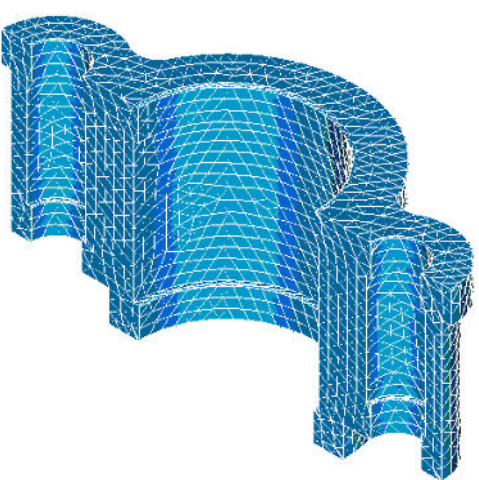

b

Figure 2 - Calculation scheme (a) and finite element model (b) of the traverse

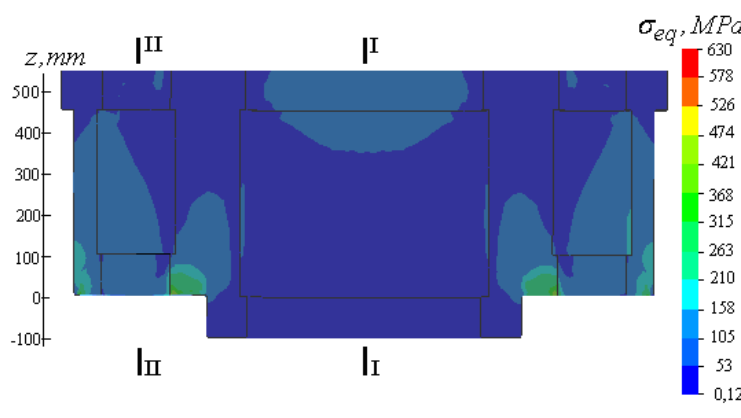

a

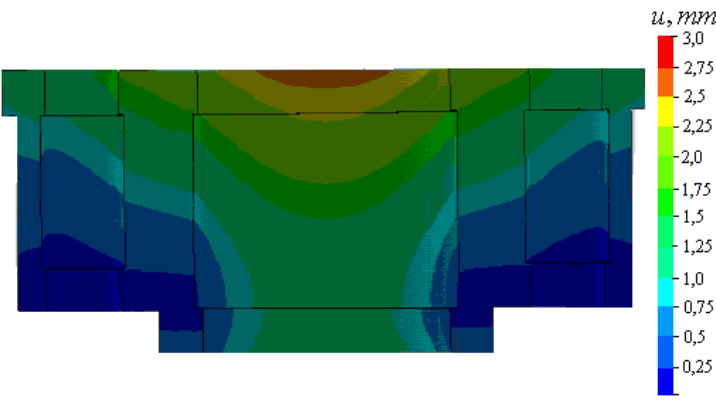

b

Figure 3 - Isosurfaces of equivalent stresses $\sigma_{e q}$ (a) and total displacements $u$ (b) 
Areas of maximum stress levels were located maximum equivalent stresses calculated by the Guber-Mises theory were observed at the points of load application, on the supporting surfaces, and in the areas of abrupt changes in geometry (Figure 3 a). The maximum equivalent stresses occurring at the points of load application are equal to $132 \mathrm{MPa}$, and at some points of the supporting surfaces they even exceed $\sigma_{y}$. Maximum total displacements are observed at the points of applying loads, while minimum displacements occur on the supports (Figure $3 \mathrm{~b}$ ).

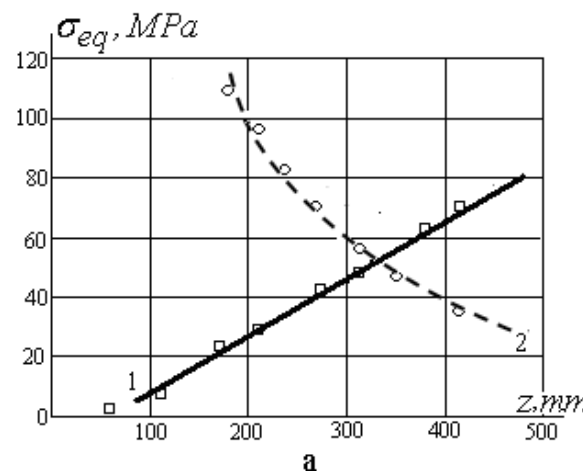

It should be noted that the equivalent stresses on the internal surfaces of the central and lateral cylinders also change significantly with the height, but the nature of their changes differs. The equivalent stresses increase with the height on the internal surface of the central cylinder in section I, while on the internal surface of the lateral cylinder in section II, they show a decrease with the height (Figure 4 a). The displacements increase in both cases (Figure 4 b).

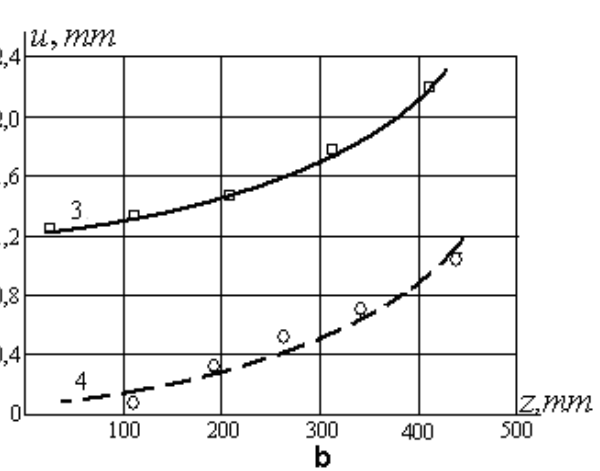

Figure 4 - Dependences of equivalent stresses and displacements on $z$-coordinate for the interior surfaces of the traverse cylindrical parts: a - dependence of equivalent stresses $\sigma_{e q}$ on $z$-coordinate: 1 - internal surface of the central cylinder (section I); 2 -internal surface of the lateral cylinder (section II); $\mathrm{b}$ - dependence of displacements $u$ on $z$-coordinate: 3 -internal surface of the central cylinder (section I); 4 - internal surface of the lateral cylinder (section II)

Furthermore, the study showed that:

- normal stresses $\sigma_{x}, \sigma_{y}, \sigma_{z}$ on the central cylinder surface in section I change according to the linear law, changing the sign at $z \approx 69.6 \mathrm{~mm}$. A relationship was found between the normal stresses: $\sigma_{x}>\sigma_{z}>\sigma_{y}$. In this case, the values $\sigma_{x}$ and $\sigma_{z}$ were an order higher than the $\sigma_{y}$ values. Linearity distortions were observed in the zones of an abrupt change in geometry. Thus, the maximum compressive stress $\sigma_{x}$ on the upper belt did not exceed $135 \mathrm{MPa}$, while inside the cylinder it did not exceed $90 \mathrm{MPa}$ (Figure 5).

- the maximum values of tangential stresses on the central cylinder surface did not exceed $1 \mathrm{MPa}$.

Thus, the study shows that the stresses on the internal surfaces of the traverse cylindrical parts and on the traverse upper belt rim do not exceed stress $[\sigma]$ for the selected material. These findings allow changing the geometry of the traverse so as to reduce its weight. The authors have proposed a traverse with the increased diameters of the internal cylindrical parts and the decreased external dimensions of the traverse upper belt. To assess the strength of the proposed traverse, an analysis of the stress fields, strains and factors of safety $n$ was performed. It was found that the increase in stresses and strains did not exceed $13 \%$.

The analysis of the $n$ diagram of the proposed traverse (Figure 6) showed that the values of factors of safety ranged from 1.8 to 6.4 (2.0-7.0 in the existing traverse) on the internal surfaces of the small cylinders, and from 3.7 to 27.3 (3.8-27.4 in the existing traverse) on the in- ternal surface of the central cylinder. The feature of the $n$ diagram is an area with overestimated factors of safety on the internal surface of the central cylinder, both for the existing and for the proposed traverse. Here, the values of $n$ exhibit a sharp increase, reaching $n=100$ at $z=69.2 \mathrm{~mm}$. It should be noted, that when $\mathrm{z} \approx 69.6 \mathrm{~mm}$, the stresses $\sigma_{x}, \sigma_{y}, \sigma_{z}$ are equal to zero, while $\sigma_{e q}$ values acquire their minimum.

Thus, the study shows that the strength and stiffness of the proposed traverse are ensured. The changes in the geometry allowed reducing the mass of the traverse by almost $13 \%$.

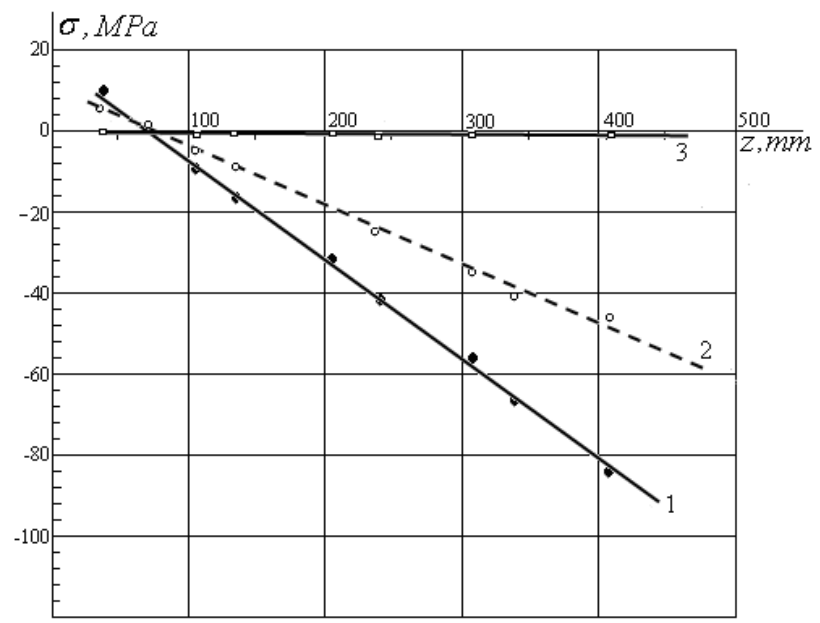

Figure 5 - Dependence of normal stresses on $z$-coordinate on the internal surface of the central cylinder in section I:

1 - normal stress $\sigma_{x} ; 2$-normal stress $\sigma_{z} ; 3$ - normal stress $\sigma_{z}$ 


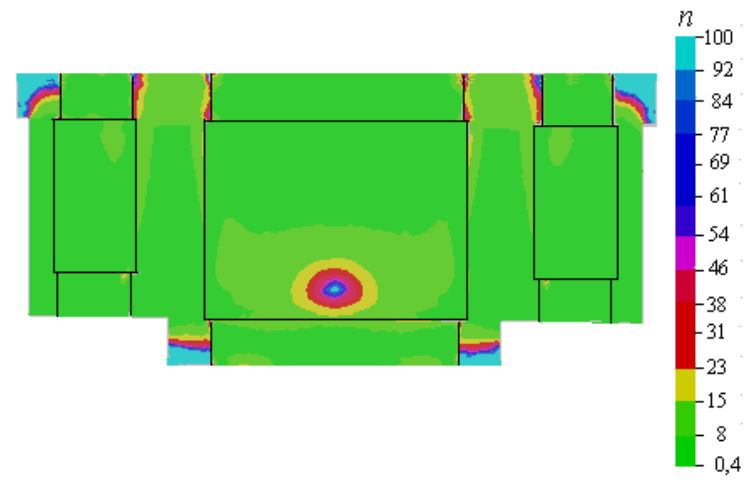

Figure 6 - Factor of Safety diagram of the proposed traverse

\section{Conclusions}

The SSS of the lower traverse of the hydraulic press, which was obtained by means of finite element modeling, is characterized by general and local uneven stresses and strains. The stress-strain analysis of the traverse revealed the zones of maximum stresses: points of load application, supports and areas of abrupt changes in geometry. It has been found that normal tensions in section I change linearly, and values $\sigma_{x}$ and $\sigma_{z}$ are an order higher than values $\sigma_{y}$. It has been established that the equivalent stresses increase with height on the internal surface of the central cylinder, and decrease on the internal surface of the lateral cylinder. The study allowed changing the geometry and reducing the weight of the traverse with a slight change in stresses and strains. The findings will have practical application in designing new and improving existing hydraulic presses.

\title{
References
}

1. Surkov, I. A. (2004). Sostoyaniye i perspektivy obespecheniya prochnostnoy nadezhnosti bazovykh detaley moshchnykh gidravlicheskikh pressov. Blank production in mechanical engineering. Forging-stamping,foundry and other production, No. 3 , 24-28 [in Russian].

2. Zhivov, L. I., Ovchinnikov, A. G., \& Skladchikov, E. N. (2006). Kuznechno-shtampovochnoye oborudovaniye. N. E. Bauman MGTU Publishing House, Moscow [in Russian].

3. Dashchenko, O. F., Kovalov, V. D., \& Lymarenko, O. M. (2012). Rozrakhunok napruzheno-deformovanoho stanu stanyny hidropresa. Pratsi Odeskoho politekhnichnoho universytetu, No 2 (39), 39-43 [in Ukrainian].

4. Dashchenko, O. F., \& Lymarenko, O. M. (2013). Napruzheno-deformovanyy stan bazovykh detaley hidravlichnykh presiv. Machine Science, No 1-2, 33-38 [in Ukrainian].

5. Surkov, A. I. (2013). Vosstanovleniye rabotosposobnosti i preduprezhdeniye razrusheniy poperechin moshchnykh gidravlicheskikh pressov s primeneniyem styazhnykh ustroystv. Chief mechanical engineer, No 10, 51-56 [in Russian].

6. Surkov, A. I., Kurovich, A. N., \& Surkov, I. A. (2003). Obespecheniye prochnostnoy nadezhnosti bazovykh detaley moshchnykh gidravlicheskikh pressov na stadiyakh proyektirovaniya i ekspluatatsii. Heavy Engineering, No. 5, 35-37 [in Russian].

7. Kamate, A. M. (2016). Design, Development and Analysis of a 20 Ton Hydraulic Press. International Journal of Innovative Technology and Research, Vol. 4, 2560-2563.

8. Burli, P. S., \& Zalake, R. M. (2015). Design optimization of Hydraulic press structure. International Journal of Latest Trends in Engineering and Technology, Vol. 5, 118-126.

9. Iancu, C. (2013). Comparision between Analytical Calculus and FEM for a Mechanical Press Bed. American Journal of Mechanical Engineering, Vol. 1, 6-13.

\section{Напружено-деформований стан нижньої траверси гідравлічного пресу}

\author{
Немчинов С. І., Начовний I. І.
}

Державний вищий навчальний заклад «Український державний хіміко-технологічний університет», просп. Гагаріна 8, 49005, м. Дніпро, Україна

\begin{abstract}
Анотація. У статті досліджено напружено-деформований стан нижньої траверси центрального виштовхувача гідравлічного преса для виготовлення великогабаритних виробів з пластмас з використанням програмного комплексу скінчено-елементного аналізу. Встановлено, що напружено-деформований стан траверси характеризується загальним і локальним нерівномірним розподілом напружень і деформацій, нормальні напруження в перерізі, що проходить через площину симетрії траверси, змінюються за лінійним законом. Виявлено різний характер зміни еквівалентних напружень по висоті на внутрішніх поверхнях центрального і бічних циліндрів. Визначено зони траверси, в яких спостерігаються максимальні напруження та деформації. Дослідження дозволило змінити геометрію траверси 3 незначною зміною напружень та деформацій і зменшити іiі вагу. Результати досліджень можуть бути застосовані при удосконаленні існуючих і проектуванні нових гідравлічних пресів, а також $є$ основою для подальших досліджень.
\end{abstract}

Ключові слова: метод скінченних елементів, геометрія, напруження, деформація, переміщення. 